\title{
Early-successional saproxylic beetles inhabiting a common host-tree type can be sensitive to the spatiotemporal continuity of their substrate
}

\author{
Mervi Laaksonen $^{1,2}$ (D) Pekka Punttila ${ }^{3} \cdot$ Juha Siitonen $^{4}$
}

Received: 3 September 2019/Revised: 31 May 2020 / Accepted: 4 June 2020 /

Published online: 12 June 2020

(C) The Author(s) 2020

\begin{abstract}
Intensive forest management has drastically reduced the amount and diversity of dead wood resulting in population decline of saproxylic species. Forestry practices can also disrupt spatiotemporal continuity of dead wood habitats. We studied the effects of standand landscape-level densities of host trees on the incidence (proportion of occupied trees) of saproxylic beetles inhabiting recently dead standing Scots pines, a common host-tree type both in natural and managed boreal forests. We compared the occurrence patterns of eight rare specialist and eight common generalist species. Saproxylic beetles were collected from a total of 315 trees in 67 forest stands, including both managed and natural forests, located in three regions which form a gradient in forest-use intensity. Species richness of the entire community at tree and stand level did not respond to the stand- and landscape-level host-tree density. The incidence of six common generalist species did not depend on the stand-level host-tree density, whereas the incidences of four rare specialist species increased with increasing host-tree density. Five out of eight rare specialist species were either significantly less common or absent from the region with the lowest landscapelevel density of host trees. We conclude that rare specialist species living in recently dead pines are susceptible to changes in spatiotemporal dynamics of their host trees. To conserve rare early-successional species, it is necessary to ensure continuous input of dying trees by prolonging rotation times in mature forests, regenerating stands using seed-tree cutting and leaving as many permanent retention trees as possible.
\end{abstract}

Keywords Forest management · Habitat specialization - Patch-tracking metapopulation · Rare species - Saproxylic beetles $\cdot$ Specialist

Communicated by Andreas Schuldt.

This article belongs to the Topical Collection: Forest and plantation biodiversity.

Electronic supplementary material The online version of this article (https://doi.org/10.1007/s10531-02002004-7) contains supplementary material, which is available to authorized users.

Extended author information available on the last page of the article 


\section{Introduction}

Dead-wood amount and diversity in many forest ecosystems worldwide are largely controlled by timber production. In Fennoscandia, intensive forest management has reduced the amount and heterogeneity of dead wood in boreal forests (Östlund et al. 1997; Jonsson et al. 2016) and has affected the spatiotemporal dynamics of dead wood (Stokland et al. 2012). As consequence, a large number of saproxylic species living on dying and dead trees has declined (Siitonen 2001).

Loss of suitable host trees will first reduce the fraction of host trees that is occupied (Andrén 1996; Hanski 2005). When the density of host trees declines below a speciesspecific threshold value, the extinction threshold, the metapopulation cannot persist in the long term (Hanski 1999). For a metapopulation living in a habitat network, there should be enough spatially connected habitats available both locally, at the stand scale, and at larger spatial scales (Hanski 1999).

Most saproxylic species are more or less specialized to use certain types of dead wood, and, consequently, the species community changes during the decay succession (Stokland et al. 2012). Dead-wood habitat is a dynamic system where patches eventually become unsuitable for the species leading to deterministic local extinctions, while simultaneously new suitable patches are formed. Populations of species living in dynamic habitat-patch networks with mainly deterministic extinctions have been termed as patch-tracking metapopulations (Thomas 1994; Snäll et al. 2003). Patch-tracking metapopulation dynamics may be common among species inhabiting temporary patches, e.g. epiphytic lichens and mosses growing on old deciduous trees (Snäll et al. 2003; Fedrowitz et al. 2012), wood-decaying fungi inhabiting spruce logs (Jönsson et al. 2008), and most probably many other saproxylic species too, such as species inhabiting the phloem layer of recently dead trees (Schroeder et al. 2007).

To survive locally, saproxylic species must colonize new host trees at the same average rate as habitat patches become unsuitable because of decomposition. Temporally continuous availability of host trees is therefore critical for the persistence of populations.

Habitat loss and increasing spatiotemporal isolation between habitat patches do not affect all species equally, but the extinction risk is connected to species-specific traits (Owens and Bennett 2000; Purvis et al. 2000). Niche breadth is associated with species response to habitat loss (e.g. Öckinger et al. 2010; Pardini et al. 2010; Seibold et al. 2015). The population densities of habitat specialists (species depending on a certain host-tree type, such as dead standing pines) will decrease whereas the population densities of generalists (species that can utilize many host-tree types) are not necessarily affected or can even increase (With and Crist 1995; Ewers and Didham 2006). Traits may interact with each other so that, for example, rarity combined with habitat specialization makes the species more vulnerable than common specialist species (Davies et al. 2004).

The aim of this study was to find out how the stand-level (local) and landscape-level (regional) density of host trees affects the occurrence patterns of saproxylic beetle species dwelling on a particular host-tree type. We chose recently dead pine as the study target because it is a clearly defined and easily distinguishable host-tree type. Recently dead pines constitute networks of short-lived habitat patches, and the density and continuity of these patches varies between forest stands and landscapes. In addition, a characteristic and species-rich beetle assemblage, including both common generalist species and several redlisted and rare specialist species, follows bark beetles in such trees. We measured the density of recently dead pines in each stand, representing the current availability of host 
trees, and the density of previously dead pines, representing the former availability and continuity of host trees in the stand. We compared the incidences of rare specialist and common generalist species measured as the proportion of host trees occupied within a forest stand, in areas where both the stand- and landscape-level densities of host trees varied.

We hypothesized that at the stand scale, (1) the incidence of rare specialist species decreases with decreasing host-tree density, whereas (2) the incidence of common generalist species should not be affected by host-tree density. At the landscape scale, (3) the incidence of rare specialists is lower, or they are completely absent, in regions with low host-tree availability when compared to natural forest landscape. In contrast, (4) common generalist species are not affected.

\section{Material and methods}

\section{Host-tree type and target species}

The subject of the study was beetle species utilizing recently dead standing Scots pines (Pinus sylvestris). This host-tree type is present also in managed forests, but at lower densities than in natural forests. The beetle fauna of recently dead pines includes early arriving species, mainly bark beetles (Curculionidae, Scolytinae) and long-horn beetles (Cerambycidae). These primary (pioneering) species are followed by a rich fauna of secondary phloem-feeders, fungivores and predators.

We selected eight rare specialist saproxylic beetles as our target species (Table 1, Table S1). The selection was based on two criteria. First, the species should be rare. The rarity of species was determined based on the frequency scores presented in the provincial list of beetles in Finland (Rassi et al. 2015). The selected species should have frequency score larger than or equal to 10 indicating that the total number of known or estimated occurrences is less than $400\left(10 \mathrm{~km}^{2} \times 10 \mathrm{~km}^{2}\right.$ squares $)$ out of 3900 squares in total. Second, the species should be strict habitat specialists in the sense that they live mainly or exclusively on recently dead standing pines. There were eight species present in the data fulfilling these criteria. Six of them are red-listed in Finland or adjacent Sweden.

We also selected eight common generalist species to function as a qualitative control in hypothesis testing (Table 1, Table S1). These were selected based on their commonness and use of dead wood types. First, the species should have frequency score 1 or 2 meaning more than 1600 occurrences in Finland and they should be common in dead pines. Second, the species should regularly use other dead wood types besides dead standing pines. We listed all the species with frequency scores 1 or 2 according to their abundances in the data. Then each species was evaluated for its use of dead wood types starting from the most abundant species. The selected species are the eight most abundant species in the data. All of these are generalists which can utilize a wider range of host-tree types, including substrates that are abundant in managed forests, such as logging-residue and cut stumps (Table 1).

Abundances, incidences and frequency scores of all the species in the data are given in Table S2. 
Table 1 The focal study species with their IUCN categories in Finland and Sweden (Rassi et al. 2010; ArtDatabanken 2015) and their host-tree preferences in Northern Europe (see references in Table S1)

\begin{tabular}{llll}
\hline Species & $\begin{array}{l}\text { Frequency } \\
\text { score in }\end{array}$ & IUCN category & Ecology \\
& Finland & Finland Sweden & \\
\end{tabular}

\begin{tabular}{|c|c|c|c|c|}
\hline \multicolumn{5}{|c|}{ Rare specialist species } \\
\hline $\begin{array}{l}\text { Boros } \\
\quad \text { schneideri }\end{array}$ & 40 & VU & EN & $\begin{array}{l}\text { Strict specialist confined to dead standing pines in the } \\
\text { boreal zone }\end{array}$ \\
\hline $\begin{array}{l}\text { Cerylon } \\
\quad \text { impressum }\end{array}$ & 40 & NT & $\mathrm{VU}$ & Strict specialist confined to dead standing pines \\
\hline $\begin{array}{l}\text { Corticeus } \\
\text { fraxini }\end{array}$ & 30 & NT & $\mathrm{VU}$ & $\begin{array}{l}\text { Mainly on pine, occasionally on spruce; larvae are } \\
\text { fungivores and facultative predators of bark beetles }\end{array}$ \\
\hline $\begin{array}{l}\text { Corticeus } \\
\quad \text { longulus }\end{array}$ & 30 & $\mathrm{LC}$ & $\mathrm{VU}$ & Specialist confined to pine \\
\hline $\begin{array}{l}\text { Corticeus } \\
\text { suturaliss }\end{array}$ & 10 & $\mathrm{LC}$ & NT & On pine and spruce \\
\hline $\begin{array}{l}\text { Epuraea } \\
\text { fussii }\end{array}$ & 15 & $\mathrm{LC}$ & $\mathrm{LC}$ & On pine and spruce \\
\hline $\begin{array}{l}\text { Leptusa } \\
\quad \text { norvegica }\end{array}$ & 20 & $\mathrm{LC}$ & $\mathrm{LC}$ & On pine and spruce \\
\hline $\begin{array}{l}\text { Plegaderus } \\
\text { saucius }\end{array}$ & 15 & $\mathrm{LC}$ & NT & Specialist confined to pine \\
\hline \multicolumn{5}{|c|}{ Common generalist species } \\
\hline $\begin{array}{l}\text { Acanthocinus } \\
\text { aedilis }\end{array}$ & 2 & $\mathrm{LC}$ & $\mathrm{LC}$ & $\begin{array}{l}\text { Mainly on pine; can utilize fallen trees, logging } \\
\text { residue tops and cut stumps }\end{array}$ \\
\hline $\begin{array}{l}\text { Placusa } \\
\text { depressa }\end{array}$ & 1 & $\mathrm{LC}$ & $\mathrm{LC}$ & $\begin{array}{l}\text { On pine and spruce; common in galleries of many bark } \\
\text { beetles }\end{array}$ \\
\hline $\begin{array}{l}\text { Phloeonomus } \\
\text { pusillus }\end{array}$ & 2 & $\mathrm{LC}$ & $\mathrm{LC}$ & $\begin{array}{l}\text { On pine and spruce; common in galleries of many bark } \\
\text { beetles }\end{array}$ \\
\hline $\begin{array}{l}\text { Plegaderus } \\
\text { vulneratus }\end{array}$ & 2 & $\mathrm{LC}$ & $\mathrm{LC}$ & $\begin{array}{l}\text { On pine and spruce; predator; common in galleries of } \\
\text { many bark beetles }\end{array}$ \\
\hline $\begin{array}{l}\text { Pytho } \\
\text { depressus }\end{array}$ & 2 & $\mathrm{LC}$ & $\mathrm{LC}$ & On pine and spruce; can utilize cut stumps \\
\hline $\begin{array}{l}\text { Rhizophagus } \\
\text { ferrugineus }\end{array}$ & 2 & $\mathrm{LC}$ & $\mathrm{LC}$ & $\begin{array}{l}\text { On pine and spruce; common in galleries of bark } \\
\text { beetles, particularly those inhabiting stumps }\end{array}$ \\
\hline $\begin{array}{l}\text { Rhagium } \\
\quad \text { inquisitor }\end{array}$ & 1 & $\mathrm{LC}$ & $\mathrm{LC}$ & $\begin{array}{l}\text { On pine, spruce and occasionally deciduous trees; can } \\
\text { utilize many types of dead wood including stumps }\end{array}$ \\
\hline $\begin{array}{l}\text { Thanasimus } \\
\text { formicarius }\end{array}$ & 2 & $\mathrm{LC}$ & $\mathrm{LC}$ & On pine and spruce; predator of bark beetles \\
\hline
\end{tabular}

Frequency scores (Rassi et al. 2015) indicate the rarity of species in Finland, based on the number of occurrences, i.e. number of $10 \times 10 \mathrm{~km}$ coordinate squares (out of 3900 squares) in Finland where the species has been recorded or assumed to occur on the bases of distribution. Rare species: scores from 10 to 40 (13 to 400 occurrences); common species: scores from 1 to 2 (at least 1600 occurrences)

\section{Study regions and stands}

The study included a total of 67 stands in three study regions. In Vienansalo, only natural stands were studied, whereas in Kuhmo and Pirkanmaa both natural and managed stands were studied (Table 2). The aim was to sample forest stands in which the density and 
Table 2 Local and regional host-tree availability in the different forest categories, number of forest stands (no. of stands with no host trees given in parentheses) and number of study trees in each category

\begin{tabular}{|c|c|c|c|c|c|c|c|}
\hline \multirow[t]{2}{*}{ Region } & \multirow[t]{2}{*}{ Management } & \multirow[t]{2}{*}{$\begin{array}{l}\text { Local host- } \\
\text { tree density }\end{array}$} & \multirow{2}{*}{$\begin{array}{l}\text { Regional } \\
\text { host-tree } \\
\text { density }\end{array}$} & \multirow[t]{2}{*}{$\begin{array}{l}\text { No. of } \\
\text { stands }\end{array}$} & \multirow{2}{*}{$\begin{array}{l}\text { No. of } \\
\text { study } \\
\text { trees }\end{array}$} & \multicolumn{2}{|c|}{$\begin{array}{l}\text { Density of dead standing } \\
\text { pines (no/ha) }\end{array}$} \\
\hline & & & & & & $\begin{array}{l}\text { Recently } \\
\text { dead }\end{array}$ & $\begin{array}{l}\text { Previously } \\
\text { dead }\end{array}$ \\
\hline Vienansalo & Natural & High & High & 10 & 100 & $\begin{array}{l}2.3 \pm 0.8 \\
\mathrm{a}\end{array}$ & $43.6 \pm 9.9 \mathrm{a}$ \\
\hline Kuhmo & Natural & High & Intermediate & 8 & 69 & $\begin{array}{l}1.2 \pm 0.7 \\
\mathrm{ab}\end{array}$ & $26.9 \pm 6.0 \mathrm{a}$ \\
\hline Kuhmo & Managed & \pm Low & Intermediate & $12(1)$ & 55 & $\begin{array}{l}3.5 \pm 3.1 \\
\mathrm{a}\end{array}$ & $\begin{array}{l}50.0 \pm 23.5 \\
\mathrm{ab}\end{array}$ \\
\hline Pirkanmaa & Natural & High & Low & 5 & 43 & $\begin{array}{l}0.5 \pm 0.5 \\
\mathrm{bc}\end{array}$ & $3.9 \pm 4.4 \mathrm{bc}$ \\
\hline Pirkanmaa & Managed & Low & Low & $\begin{array}{l}32 \\
(13)\end{array}$ & 48 & $\begin{array}{l}0.4 \pm 0.5 \\
\quad \mathrm{c}\end{array}$ & $2.1 \pm 2.5 \mathrm{c}$ \\
\hline $\begin{array}{l}\text { Total/H } \\
\text { (p) }\end{array}$ & & & & $\begin{array}{l}67 \\
(14)\end{array}$ & 315 & $\begin{array}{r}\mathrm{H}=46.83 \\
(<0.01)\end{array}$ & $\begin{array}{r}\mathrm{H}=36.53 \\
(<0.01)\end{array}$ \\
\hline
\end{tabular}

Density of recently and previously dead standing pines (mean \pm SD) are given in natural and managed forests in the three study regions. The differences in host-tree densities among the forest categories were tested with Kruskall-Wallis test $(\mathrm{H})$ and and Dunn's post-hoc test with Bonferroni correction (categories not sharing a letter differ significantly from each other)

continuity of suitable host trees varied at stand- and landscape scales. The three regions vary in their forest-utilization histories from natural landscape of Vienansalo to moderate forest-use intensity in Kuhmo and to long history of intensive forest use in Pirkanmaa.

The regions were situated in Vienansalo in Viena Karelia, Russia $\left(65^{\circ} \mathrm{N}, 30^{\circ} \mathrm{E}\right)$, Kuhmo municipality in Kainuu region in eastern Finland $\left(64^{\circ} \mathrm{N}, 29^{\circ} \mathrm{E}\right)$, and Pirkanmaa region in southwestern Finland $\left(62^{\circ} \mathrm{N}, 24^{\circ} \mathrm{E}\right)$. Vienansalo and Kuhmo are located in the middle boreal zone, and Pirkanmaa lies on the border of southern and middle boreal zones (Ahti et al. 1968) (Fig. 1).

Vienansalo is a roadless forest tract and it is one of the largest natural, uninhabited boreal forest landscapes in the middle boreal zone in Northern Europe (Lloyd 1999). The core of the area is Kalevalskiy National Park founded in 2006 and covering an area of 740 $\mathrm{km}^{2}$. Vienansalo, consisting of natural forests, serves as a reference landscape for the other two study regions. Pine forests dominate the landscape except on lower slopes of hillsides where spruce dominates (Karjalainen and Kuuluvainen 2002). The forests are mostly multi-aged with old pines over 250 years old occurring throughout the study region (Kuuluvainen et al. 2002). About $70 \%$ of the pine forests in Vienansalo are more than 140 years old (Karjalainen and Kuuluvainen 2002; Leena Karjalainen pers. comm.). The volume of dead wood was $70 \mathrm{~m}^{3} /$ ha in Vienansalo (Karjalainen and Kuuluvainen 2002).

In Kuhmo, extensive clear-cut harvesting started in the 1950s. Slash-and-burn cultivation and tar production were important sources of livelihood until the end of 1800s, and selective logging of large trees increased after the 1850s. Pine-dominated forests covered $78 \%$ of the forest area (Tomppo et al. 2003). The volume of dead wood was $6.2 \mathrm{~m}^{3} / \mathrm{ha}$ (Tomppo et al. 2003). Over 140-years-old pine forests covered $4.8 \%$ of all forest land in Kainuu (Tomppo et al. 2003). 


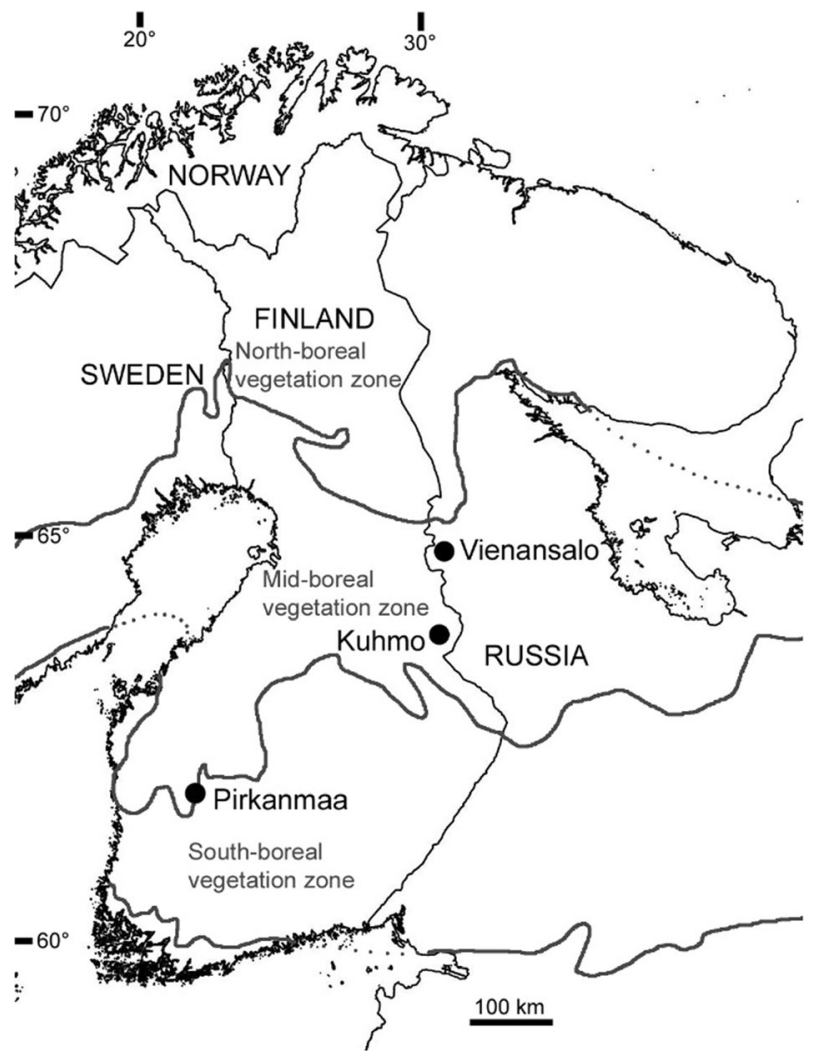

Fig. 1 Locations of the study regions Vienansalo (Kalevalskiy National Park) in Russia, Kuhmo and Pirkanmaa in Finland

Forest utilization started earlier in Pirkanmaa than in Kuhmo. Large trees were selectively logged already during the eighteenth century. Pine-dominated forests covered $52 \%$ of the forest area (Korhonen et al. 2000). The volume of dead wood was $2.4 \mathrm{~m}^{3} / \mathrm{ha}$ in Pirkanmaa (Korhonen et al. 2000) at the time of our study. Over 140-years-old pine forests covered $1.7 \%$ of all forest land in Pirkanmaa (Korhonen et al. 2000).

The study stands were randomly selected using the following criteria: (i) pine-dominated, (ii) stand area at least 2 ha, and (iii) distance to the nearest selected stand at least $1 \mathrm{~km}$. The successional stage of the studied stands varied from mature to old-growth, including some seed-tree stands with mature pines in the managed-forest category. The natural forests in Kuhmo and Pirkanmaa were selected from protected areas with oldgrowth pine forests based on prior information. All the stands were selected within an area of $4 \mathrm{~km} \times 6 \mathrm{~km}$ in Vienansalo, $15 \mathrm{~km} \times 15 \mathrm{~km}$ in Kuhmo, and $90 \mathrm{~km} \times 35 \mathrm{~km}$ in Pirkanmaa, where old-growth pine forests were few and far between.

\section{Stand characteristics}

We measured the density of recently dead pines (trees that have died $\leq 2$ years ago) and the density of previously dead pines (died $>2$ years ago) on a larger sample plot within 
the study stands (resource survey). Density was calculated as the number of trees (diameter at breast height, $\mathrm{DBH} \geq 15 \mathrm{~cm}$ ) per hectare (Table S3). In natural forests, the resource survey plot was on average 2.6 ha (1.8-4.0 ha) in Vienansalo, 10.0 ha (3.0-34.0 ha) in Kuhmo, and 2.3 ha (1.8-2.7 ha) in Pirkanmaa. In managed forests, the plot was on average 9.8 ha (4.7-19.7 ha) in Kuhmo and 5.8 ha (2.0-9.4 ha) in Pirkanmaa. Resource survey plots were randomly placed within each stand. The whole stand area was inventoried if the stand was relatively small or there were only few dead pines available within the stand. The time of death of the tree was determined by visual inspection of bark looseness, presence of needles and small twigs, and the colour of needles if present.

Forest stand characteristics (i.e. basal area of living trees and volume of dead wood) were measured in the field (see Online Appendix 2 for further methodological details). Natural forests in Vienansalo, Kuhmo and Pirkanmaa did not differ from each other in the volumes of living and dead wood (Table S3). The volume and density of dead standing pines was lowest in Pirkanmaa managed forests, but they were not significantly different from Kuhmo because of large variation among the stands.

\section{Species survey}

In each stand, we selected randomly a total of 10 pines $(\mathrm{DBH} \geq 15 \mathrm{~cm})$ among the dead trees that we found in the resource survey. The study trees had died during one to two years ago. If there were fewer than 10 trees, all the suitable trees were sampled. A total of 315 trees were included into the study (Table 2).

To collect beetles, we first set a white canvas around the root neck of the study trunk. Next, we peeled the bark with a knife and an axe for an area of $1 \mathrm{~m}^{2}$ at the base of the trunk. Using standard-sized sample plots enabled the comparisons of species richness and occurrence of species between individual trees. The fieldwork was carried out during 1998-1999 between May and September.

We collected all the beetle larvae and adults except larvae of bark beetles (Curculionidae, Scolytinae) for identification. The loose bark and insect frass were sieved and inspected for any beetles on a white tray in the field or in a laboratory. All the adult individuals were identified to the species level as was part of the larval material (Cerambycidae and species in the genera Boros, Corticeus, Dendrophagus, Gabrius, Glischrochilus, Harminius, Leptusa, Nudobius, Melanotus, Pediacus, Plegaderus, Pytho, Thanasimus, Rhizophagus and Zilora). Only the material identified to the species level was included in the analyses. Nomenclature of the beetles follows Silfverberg (2010).

\section{Data analyses}

To test differences in the mean densities of dead standing pines and species richness on tree level between the forest categories, we applied the non-parametric Kruskall-Wallis test and Dunn's post-hoc tests with Bonferroni correction using add-on package PMCMR (Pohlert 2014). There were no host trees in 14 managed stands. These stands were included in calculating the average densities of dead standing pines $(n=67$, see Table 2$)$ but they were excluded from analyses concerning the incidence of species $(n=53$, Table 2$)$.

To compare species richness among forest categories at the stand level, we employed EstimateS 9.1.0 (Colwell 2013) to count the mean number of species (S mean) in the pooled samples of 1-10 study trees in 100 runs. Individuals were randomized with replacement. 
We examined the effects of the availability of host trees on the incidences of the selected sixteen species (Table 1) using generalized linear models (GLM). Two of the selected specialist species (Corticeus longulus and Boros schneideri) were excluded from the analyses because they were too scarce in the material to allow for testing their incidences. The response variable was the incidence of each species, i.e. the number of trees occupied by the species out of all the trees studied within a stand. The explanatory variables were the densities of recently dead and previously dead host trees in each stand, and the study region (as a surrogate for the regional density of host trees). GLMs were conducted using a logit link function and assuming a binomial error distribution to account for variation in the number of study trees among stands. Zero-inflated model (ZIB) with intercept only to the ZI-part was applied in case of overdispersion caused by zero-inflation using add-on package glmmTMB (Brooks et al. 2017). In other cases of overdispersion, GLM was conducted assuming a quasibinomial distribution. All the analyses were performed in R 3.5.1 ( $\mathrm{R}$ Core Team 2018).

\section{Results}

\section{Species richness}

In the 315 study trees, a total of 43,308 individuals of 147 species were recorded. The average number of species per study tree varied between 10.1 and 12.6 and did not differ significantly between the five forest categories $(\mathrm{H}=4.1, \mathrm{df}=4, \mathrm{p}=0.39$; Fig. 2a).

In the pooled samples of 1-10 study trees, the average species numbers per forest stand were similar, based on the overlapping confidence intervals, between the forest categories (Fig. 2b). Average species numbers per stand were slightly lower in Vienansalo than in the other areas.

(a)

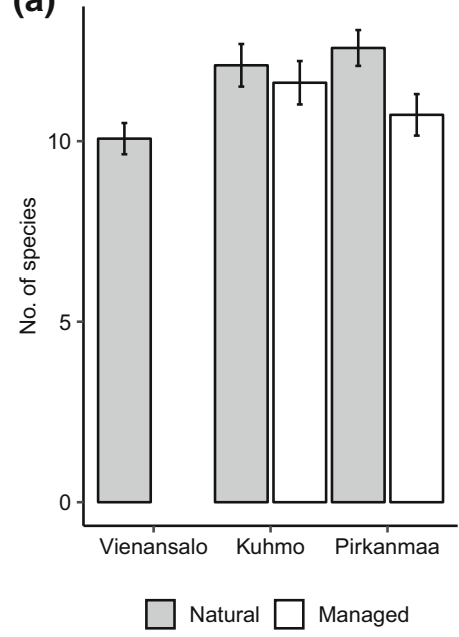

(b)

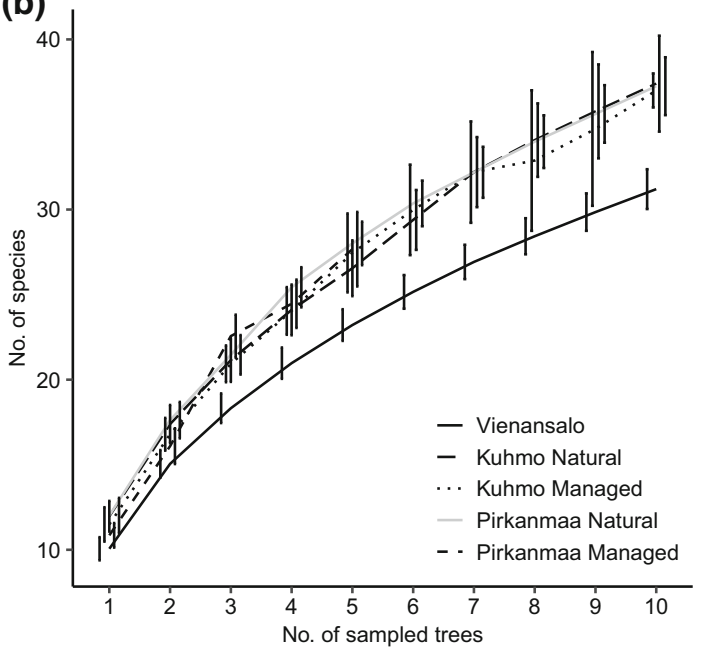

Fig. 2 Species richness (mean \pm SE) a per study tree for each forest category and $\mathbf{b}$ per forest stand in the pooled samples of 1-10 study trees in 100 runs 


\section{Species incidences}

The median incidences of the eight selected rare specialist species were clearly higher in natural than in managed forests (Fig. 3), whereas there were no clear differences between natural and managed forests in the incidences of the eight selected common generalist species (Fig. 4).

According to the GLM results, the density of previously dead host trees had a significant positive effect on the incidence of four out of the six specialist species included in the analyses (Table 3), namely Corticeus suturalis, Cerylon impressum, Leptusa norvegica and Plegaderus saucius. The density of previously dead host trees had a significant effect on the incidence of only one generalist species, Rhagium inquisitor (Table 3). The density of
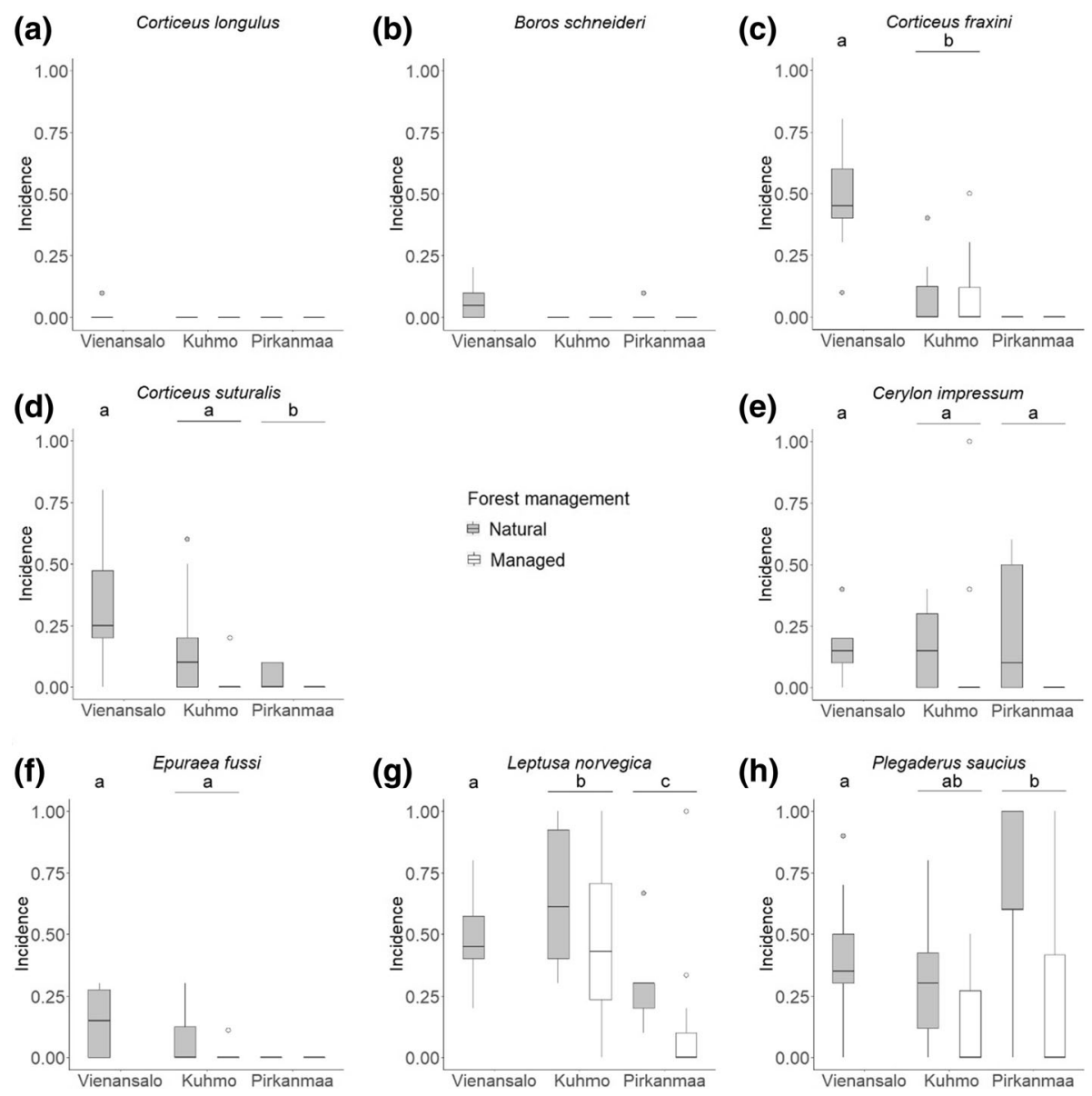

Fig. 3 Incidences (proportion of occupied trees; quartiles, min and max indicated) of eight rare specialist species in the three study regions (high, intermediate and low regional host tree density) and two management categories (natural and managed). Significant differences between regions according to GLM results (Table 3) are indicated with letters $(\mathbf{a}-\mathbf{c})$. Differences between regions were tested conditional on host tree densities 

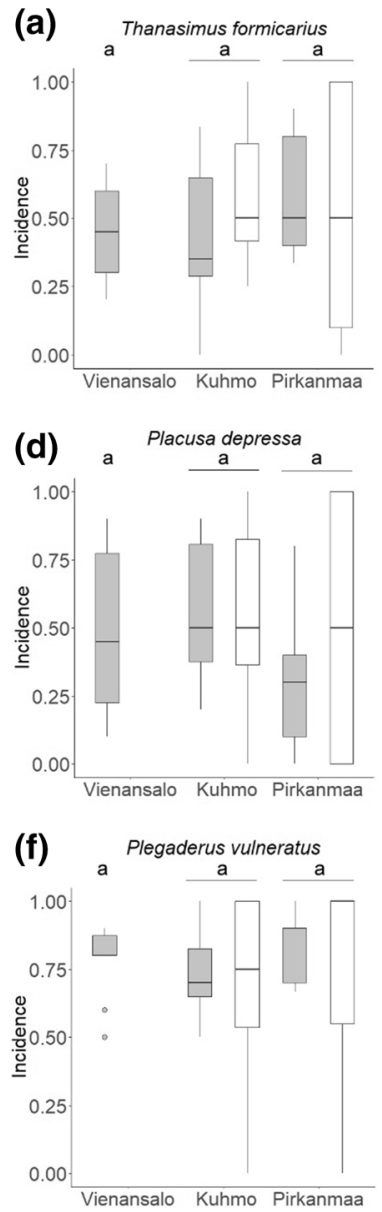
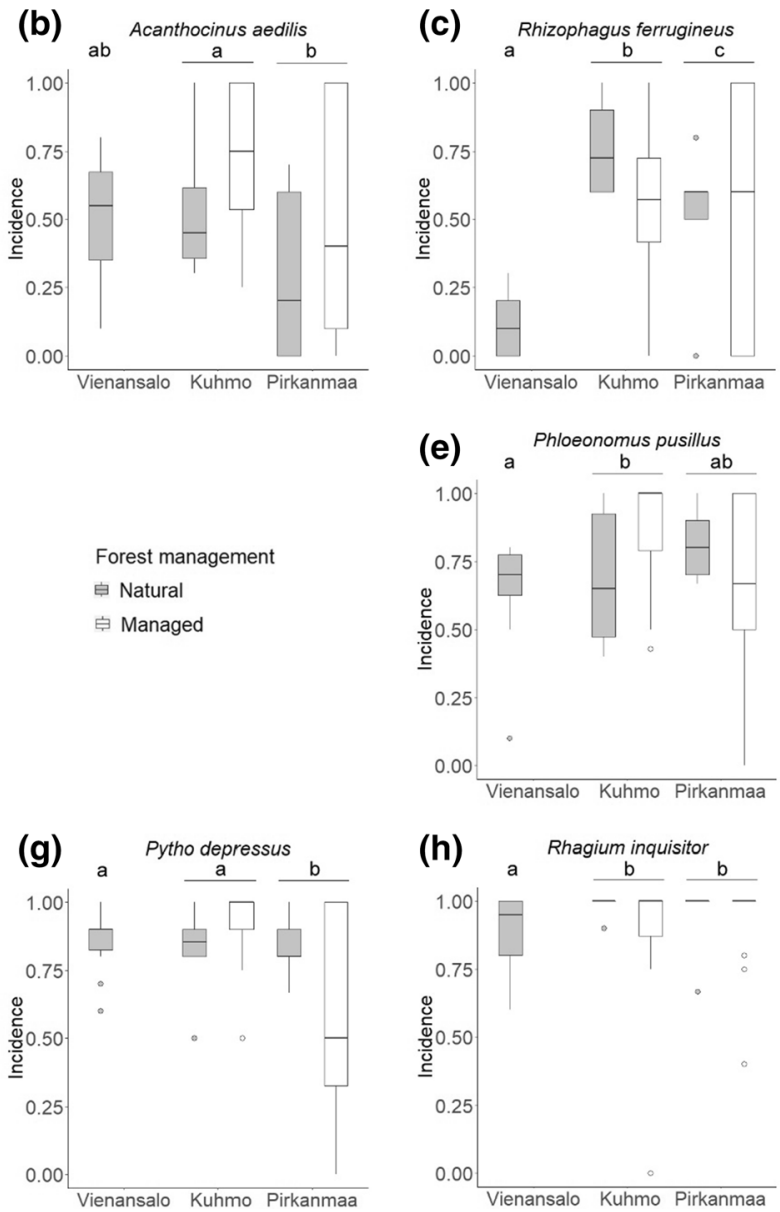

Fig. 4 Incidences (proportion of occupied trees; quartiles, min and max indicated) of eight common generalist species in the three study regions (high, intermediate and low regional host tree density) and two management categories (natural and managed)

recently dead host trees had no effect on the incidences of specialist species, and affected significantly only one generalist species, Pytho depressus (Table 3).

Two specialist species were significantly more common in Vienansalo and Kuhmo than in Pirkanmaa (Table 3). Additionally, Corticeus fraxini and Epuraea fussi were totally missing from Pirkanmaa in our dataset. Furthermore, of the two species not tested, Corticeus longulus was found only in one stand in Vienansalo, and Boros schneideri in several stands in Vienansalo and one natural stand in Pirkanmaa. Incidences of P. saucius and $C$. impressum did not differ between the regions (Table 3). The generalist species did not show differences in their incidences among the regions, or some of them were more common in Kuhmo and Pirkanmaa than in Vienansalo (Table 3). Pytho depressus was as common in Kuhmo as in Vienansalo but less common in Pirkanmaa (Fig. 4, Table 3). 
Table 3 Generalized linear models presented with species' incidences as response variables

\begin{tabular}{|c|c|c|c|c|c|c|c|}
\hline Species & Variable & Estimate & SE & $\begin{array}{l}\text { z/t- } \\
\text { value }^{b}\end{array}$ & $\begin{array}{l}\mathrm{p}- \\
\text { value }\end{array}$ & $\begin{array}{l}\text { Residual } \\
\text { deviance }\end{array}$ & df \\
\hline \multicolumn{8}{|l|}{ Rare specialist species } \\
\hline \multirow[t]{4}{*}{ Corticeus fraxini ${ }^{\mathrm{a}}$} & Intercept & -0.33 & 0.80 & $-0.32^{\mathrm{b}}$ & 0.75 & & \\
\hline & Region Kuhmo & -1.93 & 0.57 & $-2.63^{b}$ & 0.01 & & \\
\hline & Current density & -0.03 & 0.24 & $-0.08^{b}$ & 0.94 & & \\
\hline & Former density & -0.08 & 0.02 & $0.36^{\mathrm{b}}$ & 0.71 & 44.47 & 25 \\
\hline \multirow[t]{5}{*}{ Corticeus suturalis } & Intercept & -2.25 & 0.67 & -3.35 & $<0.01$ & & \\
\hline & Region Kuhmo & -0.62 & 0.49 & -1.28 & 0.20 & & \\
\hline & $\begin{array}{l}\text { Region } \\
\text { Pirkanm }\end{array}$ & -2.85 & $\mathbf{0 . 8 0}$ & -3.58 & $<0.01$ & & \\
\hline & Current density & -0.34 & 0.23 & -1.45 & 0.14 & & \\
\hline & $\begin{array}{l}\text { Former } \\
\text { density }\end{array}$ & 0.05 & 0.01 & 3.07 & $<0.01$ & 53.35 & 48 \\
\hline \multirow[t]{5}{*}{ Cerylon impressum } & Intercept & -3.50 & 0.52 & -6.71 & $<0.01$ & & \\
\hline & Region Kuhmo & 0.77 & 0.45 & 1.71 & 0.09 & & \\
\hline & $\begin{array}{l}\text { Region } \\
\text { Pirkanm }\end{array}$ & 0.25 & 0.46 & 0.54 & 0.59 & & \\
\hline & Current density & -0.26 & 0.18 & -1.43 & 0.15 & & \\
\hline & $\begin{array}{l}\text { Former } \\
\text { density }\end{array}$ & 0.05 & 0.01 & 3.97 & $<0.01$ & 56.21 & 48 \\
\hline \multirow[t]{4}{*}{ Epuraea fussii ${ }^{\mathrm{a}}$} & Intercept & -2.63 & 1.12 & -2.35 & 0.02 & & \\
\hline & Region Kuhmo & -0.53 & 0.02 & -0.70 & 0.49 & & \\
\hline & Current density & 0.01 & 0.35 & 0.02 & 0.98 & & \\
\hline & Former density & 0.02 & 0.02 & 0.77 & 0.44 & 35.97 & 25 \\
\hline \multirow[t]{5}{*}{ Leptusa norvegica } & Intercept & -0.64 & 0.37 & -1.71 & 0.09 & & \\
\hline & Region Kuhmo & 0.75 & $\mathbf{0 . 3 3}$ & 2.26 & 0.02 & & \\
\hline & $\begin{array}{l}\text { Region } \\
\text { Pirkanm }\end{array}$ & -1.19 & 0.36 & -3.31 & $<0.01$ & & \\
\hline & Current density & -0.11 & 0.12 & -0.91 & 0.36 & & \\
\hline & $\begin{array}{l}\text { Former } \\
\text { density }\end{array}$ & 0.02 & 0.01 & 2.07 & 0.04 & 74.90 & 48 \\
\hline \multirow[t]{6}{*}{ Plegaderus saucius ${ }^{\mathrm{c}}$} & Intercept & -2.25 & 0.49 & -4.54 & $<0.01$ & & \\
\hline & Region Kuhmo & 0.63 & 0.39 & 1.61 & 0.11 & & \\
\hline & $\begin{array}{l}\text { Region } \\
\text { Pirkanm }\end{array}$ & 1.11 & 0.43 & 2.57 & 0.01 & & \\
\hline & Current density & 0.23 & 0.13 & 1.76 & 0.08 & & \\
\hline & $\begin{array}{l}\text { Former } \\
\text { density }\end{array}$ & 0.04 & 0.01 & 3.16 & $<0.01$ & & \\
\hline & Intercept $\mathbf{Z I}$ & -1.75 & 0.59 & -2.99 & $<0.01$ & 161.9 & 47 \\
\hline \multicolumn{8}{|c|}{ Common generalist species } \\
\hline \multirow[t]{5}{*}{ Placusa depressa } & Intercept & -0.38 & 0.49 & $-0.79^{b}$ & 0.44 & & \\
\hline & Region Kuhmo & 0.54 & 0.45 & $1.18^{\mathrm{b}}$ & 0.24 & & \\
\hline & $\begin{array}{l}\text { Region } \\
\text { Pirkanm }\end{array}$ & -0.30 & 0.46 & $-0.66^{\mathrm{b}}$ & 0.51 & & \\
\hline & Current density & 0.05 & 0.14 & $0.43^{\mathrm{b}}$ & 0.67 & & \\
\hline & Former density & 0.00 & 0.01 & $0.43^{\mathrm{b}}$ & 0.67 & 113.04 & 48 \\
\hline
\end{tabular}


Table 3 continued

\begin{tabular}{|c|c|c|c|c|c|c|c|}
\hline Species & Variable & Estimate & SE & $\begin{array}{l}\mathrm{z} / \mathrm{t}- \\
\text { value }^{\mathrm{b}}\end{array}$ & $\begin{array}{l}\mathrm{p}- \\
\text { value }\end{array}$ & $\begin{array}{l}\text { Residual } \\
\text { deviance }\end{array}$ & df \\
\hline \multirow[t]{5}{*}{ Phloeonomus pusillus } & Intercept & -0.18 & 0.52 & $-0.35^{\mathrm{b}}$ & 0.73 & & \\
\hline & Region Kuhmo & 1.02 & 0.47 & $2.19^{b}$ & 0.03 & & \\
\hline & $\begin{array}{l}\text { Region } \\
\text { Pirkanm }\end{array}$ & 0.66 & 0.48 & $1.39^{\mathrm{b}}$ & 0.17 & & \\
\hline & Current density & 0.12 & 0.15 & $0.78^{b}$ & 0.44 & & \\
\hline & Former density & 0.01 & 0.01 & $0.91^{\mathrm{b}}$ & 0.36 & 90.27 & 48 \\
\hline \multirow[t]{5}{*}{ Pytho depressus } & Intercept & 1.42 & 0.48 & 2.98 & $<0.01$ & & \\
\hline & Region Kuhmo & 0.24 & 0.45 & 0.53 & 0.59 & & \\
\hline & $\begin{array}{l}\text { Region } \\
\text { Pirkanm }\end{array}$ & -0.86 & 0.43 & -2.01 & 0.04 & & \\
\hline & $\begin{array}{l}\text { Current } \\
\text { density }\end{array}$ & 0.44 & 0.19 & 2.38 & 0.02 & & \\
\hline & Former density & -0.01 & 0.01 & -1.12 & 0.26 & 70.16 & 48 \\
\hline \multirow[t]{5}{*}{ Rhagium inquisitor } & Intercept & -0.01 & 0.87 & -0.01 & 0.99 & & \\
\hline & Region Kuhmo & 2.31 & 0.80 & 2.90 & $<0.01$ & & \\
\hline & $\begin{array}{l}\text { Region } \\
\text { Pirkanm }\end{array}$ & 2.02 & 0.83 & 2.43 & 0.02 & & \\
\hline & Current density & -0.14 & 0.21 & -0.66 & 0.51 & & \\
\hline & $\begin{array}{l}\text { Former } \\
\text { density }\end{array}$ & 0.05 & 0.02 & 2.62 & $<0.01$ & 52.61 & 48 \\
\hline \multirow{5}{*}{$\begin{array}{l}\text { Thanasimus } \\
\text { formicarius }\end{array}$} & Intercept & -0.63 & 0.35 & -1.78 & 0.08 & & \\
\hline & Region Kuhmo & 0.36 & 0.32 & 1.13 & 0.26 & & \\
\hline & $\begin{array}{l}\text { Region } \\
\text { Pirkanm }\end{array}$ & 0.48 & 0.33 & 1.46 & 0.15 & & \\
\hline & Current density & 0.21 & 0.11 & 1.95 & 0.05 & & \\
\hline & Former density & 0.06 & 0.02 & 2.62 & $<0.01$ & 77.76 & 48 \\
\hline \multirow[t]{5}{*}{ Acanthocinus aedilis } & Intercept & -0.20 & 0.45 & $-0.45^{\mathrm{b}}$ & 0.66 & & \\
\hline & Region Kuhmo & 0.37 & 0.42 & $0.89^{\mathrm{b}}$ & 0.38 & & \\
\hline & $\begin{array}{l}\text { Region } \\
\text { Pirkanm }\end{array}$ & -0.45 & 0.43 & $-1.04^{\mathrm{b}}$ & 0.30 & & \\
\hline & Current density & 0.11 & 0.13 & $0.88^{\mathrm{b}}$ & 0.38 & & \\
\hline & Former density & -0.00 & 0.01 & $-0.11^{\mathrm{b}}$ & 0.91 & 103 & 48 \\
\hline \multirow{5}{*}{$\begin{array}{l}\text { Rhizophagus } \\
\text { ferrugineus }\end{array}$} & Intercept & -0.20 & 0.45 & -0.45 & 0.66 & & \\
\hline & Kuhmo & 3.09 & 0.41 & 7.47 & $<0.01$ & & \\
\hline & Pirkanmaa & 2.25 & 0.41 & 5.48 & $<0.01$ & & \\
\hline & Current density & 0.18 & 0.11 & 1.64 & 0.10 & & \\
\hline & Former density & -0.00 & 0.01 & -0.10 & 0.92 & 88.84 & 48 \\
\hline
\end{tabular}


Table 3 continued

\begin{tabular}{llcccccc}
\hline Species & Variable & Estimate & SE & $\begin{array}{l}\text { z/t- } \\
\text { value }^{\mathrm{b}}\end{array}$ & $\begin{array}{l}\mathrm{p}- \\
\text { value }\end{array}$ & $\begin{array}{l}\text { Residual } \\
\text { deviance }\end{array}$ & $\mathrm{df}$ \\
\hline Plegaderus vulneratus & Intercept & 0.72 & 0.45 & 1.60 & 0.11 & \\
& $\begin{array}{l}\text { Region Kuhmo } \\
\text { Region }\end{array}$ & 0.03 & 0.39 & 0.07 & 0.95 & \\
& $\begin{array}{l}\text { Pirkanm } \\
\text { Current density }\end{array}$ & 0.16 & 0.42 & 0.84 & 0.40 & \\
& Former density & 0.00 & 0.01 & 0.43 & 0.67 & 68.97 & 48 \\
\hline
\end{tabular}

Explanatory variables include stand-level host tree density of recently (current density) and previously (former density) dead standing pines and region (as a surrogate of regional host tree density) as categorical variable with Vienansalo as a reference group. Statistically significant variables are indicated with boldface

${ }^{\mathrm{a}}$ The species is missing from Pirkanmaa in this dataset and thus the region is omitted from the analysis for this species

${ }^{b}$-value given for quasibinomial models

${ }^{c}$ Zero-inflation model (ZIB) results are given for the species. ZI-part with intercept only

\section{Discussion}

We studied how the density and continuity of suitable host trees affects the occurrence of eight rare specialist and eight common generalist saproxylic beetles at the stand and landscape scales. Recently dead pines occur frequently also in managed forests. This would superficially imply that species specialized on such a common host-tree type are not likely to become threatened. In our study we show that this is not the case but, in line with our hypotheses, the rare specialist species inhabited a lower proportion of suitable trees when the density of host trees declined. Three of the rare specialist species were absent even from natural stands with high densities of host trees in study regions with longer forest-use history and lower host-tree availability, which may indicate regional extinctions.

At the stand scale, the incidence of four out of six rare specialist species that could be tested depended significantly on the density of previously dead host trees, which indicates that local continuity of host trees is important for these species. In contrast, only one of the eight common generalist species responded positively to the density of previously dead host trees. This difference between specialists and generalists is probably due to the species' habitat requirements. At times when recently dead standing pines are not available, habitat generalists can inhabit other types of dead wood, thus rendering population uninfluenced by the temporary paucity of dying trees and increasing distances between these patches. Some species may even benefit from intensive timber extraction if new habitat patches emerge along with it. All the generalist species analysed in this study reproduce successfully also in dead-wood types that are common in intensively managed forests, such as cut stumps and logging-residue tops and bolts, whereas none of the specialist species included in our analyses reproduces in these dead-wood types.

The density of recently dead host trees explained significantly the incidence of only one common generalist species and none of the rare specialist species. Although the density of recently dead host trees describes the quality of the habitat patch at the moment, it is likely that species cannot respond to it immediately by inhabiting a larger proportion of available trees. Thus, it may be hypothesized that current availability of host trees was not as significant variable as former availability of host trees since the latter is linked to the 
spatiotemporal amount and connectivity of habitat (see Sverdrup-Thygeson et al. 2014). However, it has to be noted that the variation in the former density of host trees (0-91 trees per ha) was about ten times larger than the variation in the current density of host trees ( $0-8$ trees per ha), which makes the former availability statistically more likely to show a significant effect.

At the landscape scale, the incidence of four out of six rare specialist species that could be tested decreased significantly along the management-intensity gradient as expected. Three specialist species were absent even from natural stands with high densities of host trees in the region with the longest forest-use history. In contrast, only one of the eight common generalist species had a lower incidence whereas two had higher incidences in either of the managed regions than in the reference landscape with natural forest.

We suggest that differences in stand dynamics and, consequently, differences in hosttree availability between natural and managed forests are the key explanations for the lower incidence or absence of rare specialist species in managed forests. In natural conditions, the continuous input of dead standing pines may enable both rare species and species with low dispersal capacity to persist. In natural forests, most pines die as standing trees (Karjalainen and Kuuluvainen 2002; Rouvinen et al. 2002a). The predominant mode of disturbance in pine-dominated natural forests in Fennoscandia used to be low-intensity surface fires, which led to partial mortality and cohort dynamics (Kuuluvainen and Aakala 2011). Autogenic mortality of individual trees or small groups of trees is also common, resulting in continuous recruitment of dead standing pines and a more or less uniform distribution of such trees at the landscape level (Rouvinen et al. 2002b; Kuuluvainen et al. 2017).

The densities of recently and previously dead standing pines were clearly lower in mature managed than in natural stands. Recently dead pines were completely missing from about a third of the managed stands. In managed forest landscapes where stands are regenerated by clear-cutting or seed-tree cutting soon after they reach maturity, and where young and middle-aged forests are treated with thinnings, natural mortality of trees has diminished. Thus, forest management affects the spatiotemporal dynamics of dead trees in two ways. Firstly, it slows down the rate at which new host trees emerge while the average lifetime of suitable host trees remains at the same level. The input rate of dead standing pines was about 2-10 times higher in natural than in managed forests, and the difference in the density of previously dead pines was several times higher than that.

Secondly, regeneration cutting of mature stands reduces the lifespan of habitat patches with recently dead, large trees and increases the average distance between such patches. If a specialist species goes locally extinct in a stand located in managed landscape, the probability of recolonization from the surroundings may be low. In contrast, a stand located in natural forest landscape is likely to be surrounded by stands with suitable host trees thus allowing recolonization.

Sverdrup-Thygeson et al. (2017) showed that specialist saproxylic beetle species dependent on old oaks showed a positive response to the amount of suitable host trees at a small scale $(0.5 \mathrm{~km})$, whereas for generalist species there was no or only a weak response and only at the largest scale $(25 \mathrm{~km})$ tested. The differences in response to habitat connectivity between specialists (most of which were red-listed) and generalists were explained by differences in traits such as body size and feeding habits. Similarly, Brunet and Isacsson (2009) observed that the number of red-listed saproxylic beetles living on beech snags decreased with distance to old-growth forest and increased with snag density within 200-300 m, whereas the number of non-red-listed species was not correlated with isolation from old-growth forest. These results suggested that red-listed species may have a 
lower dispersal capacity than other saproxylic beetles. Although species adapted to shortlived habitats are generally more dispersive than species of more stable habitats, the average spatial scale at which specialist beetle species inhabiting recently dead aspens responded to habitat connectivity was about $100 \mathrm{~m}$ (Ranius et al. 2011).

Recently dead pines constitute networks of short-lived habitat patches for species feeding on phloem and for species associated with them. The early-successional species occupy a tree for only one generation before it turns unsuitable. New individuals leave the patch simultaneously when it becomes unsuitable and subsequently colonize empty patches, suggesting patch-tracking metapopulation dynamics. When habitat patches are shortlived and new ones are frequently formed, this kind of pulsed dispersal generally promotes colonization, increases occupancy, and prolongs metapopulation persistence (Reigada et al. 2015). However, the advantages of pulsed dispersal on colonization rates are restricted to metapopulations living in landscapes composed of a high number of habitat patches. Conversely, in small landscapes (consisting of a low number of available habitat patches) pulsed dispersal causes high population fluctuations, low patch occupancy and high extinction risk (Reigada et al. 2015).

The key factor in dynamic landscapes determining species persistence is their capability to maintain per-patch colonization rate greater than the rate at which patches become unsuitable (Keymer et al. 2000; Reigada et al. 2015). If the rate at which new patches appear is slowed down, spatiotemporal isolation, i.e. distances both in space and time, increases and spatiotemporal connectivity is degraded. When habitat is fragmented into a set of disconnected clusters embedded in non-habitable matrix, patch occupancy is depressed since habitat fragmentation prevents species from propagating through the landscape keeping occupancy restricted to small clusters (Keymer et al. 2000).

Although several specialist species had lower incidence or were absent from managed forests, species richness at both the tree and stand levels were similar in natural and managed forests within and between regions. This indicates that lost species in managed sites are compensated by occasional species from the matrix and other types of dead-wood microhabitats. In Vienansalo, the numbers were slightly lower indicating a reverse condition, in which old pine-dominated forests with similar species composition surround the study sites.

The managed stands that we studied represent the oldest age classes in managed forests. The average age of managed forests studied was about 140 years in Kuhmo and 120 years in Pirkanmaa, which means that these stands have regenerated naturally in the $1800 \mathrm{~s}$. Intensive forest management based on clear-cutting, soil preparation and planting started at large scale in Finland only from the beginning of 1950s. In the future, an ever-increasing proportion of mature managed forests originates from clear-cutting and has been managed from the beginning. This will probably further reduce the input rate of recently dead standing pines.

To conserve species living in dead-wood habitats, it is necessary to leave dead wood during harvesting operations. For rare and red-listed early-successional species, spatially and temporally continuous input of dying trees is the critical factor. The probability of persistence of these species can be increased by prolonging rotation times in mature forests, regenerating stands using seed-tree cutting and leaving as many permanent retention trees as possible. All these measures increase the amount of old pines and, in the long term, the availability of large dead pines in the managed-forest landscape. As consequence, these measures both increase the probability of persistence of species at the stand level, and at the same time increase the spatiotemporal links between stands at the 
landscape level. Such measures benefit large numbers of other saproxylic organisms using dead-wood habitats of later decay-succession phases too.

The present study was confirmatory in its nature. We concentrated on only one specific dead-wood type, and on testing hypotheses concerning the occurrence patterns of a limited, preselected set of rare specialists versus common generalist species, which may also limit the generalizability of the results. An alternative approach would include testing the occurrence patterns of all the species, to assess which proportion of species respond to local or regional host-tree density, and to explore which other traits than rarity and degree of specialization might explain species' responses.

Acknowledgements Open access funding provided by University of Helsinki including Helsinki University Central Hospital.

Data availability The datasets analysed during the current study are available from the corresponding author on reasonable request.

\section{Compliance with ethical standards}

Conflict of interest The authors declare that they have no conflict of interest.

Open Access This article is licensed under a Creative Commons Attribution 4.0 International License, which permits use, sharing, adaptation, distribution and reproduction in any medium or format, as long as you give appropriate credit to the original author(s) and the source, provide a link to the Creative Commons licence, and indicate if changes were made. The images or other third party material in this article are included in the article's Creative Commons licence, unless indicated otherwise in a credit line to the material. If material is not included in the article's Creative Commons licence and your intended use is not permitted by statutory regulation or exceeds the permitted use, you will need to obtain permission directly from the copyright holder. To view a copy of this licence, visit http://creativecommons.org/licenses/by/4.0/.

\section{References}

Ahti T, Hämet-Ahti L, Jalas J (1968) Vegetation zones and their sections in northwestern Europe. Ann Bot Fenn 5:169-211

Andrén H (1996) Population responses to habitat fragmentation: statistical power and the random sample hypothesis. Oikos 76:235-242

ArtDatabanken (2015) Rödlistade arter i Sverige 2015. ArtDatabanken SLU, Uppsala

Brooks ME, Kristensen K, van Benthem KJ, Magnusson A, Berg CW, Nielsen A, Skaug HJ, Maechler M, Bolker BM (2017) glmmTMB balances speed and flexibility among packages for zero-inflated generalized linear mixed modeling. R J 9:378-400

Brunet J, Isacsson G (2009) Restoration of beech forest for saproxylic beetles-effects of habitat fragmentation and substrate density on species diversity and distribution. Biodivers Conserv 18:2387-2404

Colwell RK (2013) EstimateS: statistical estimation of species richness and shared species from samples. Version 9. User's Guide and application. https://purl.oclc.org/estimates. Accessed 14 Feb 2019

Davies KF, Margules CR, Lawrence JF (2004) A synergistic effect puts rare, specialized species at greater risk of extinction. Ecology 85:265-271. https://doi.org/10.1890/03-0110

Ewers R, Didham R (2006) Confounding factors in the detection of species responses to habitat fragmentation. Biol Rev 81:117-142. https://doi.org/10.1017/S1464793105006949

Fedrowitz K, Kuusinen M, Snäll T (2012) Metapopulation dynamics and future persistence of epiphytic cyanolichens in a European boreal forest ecosystem. J Appl Ecol 49:493-502

Hanski I (1999) Metapopulation ecology. Oxford University Press Inc., New York, p 324

Hanski I (2005) The shrinking world: ecological consequences of habitat loss. Excellence in ecology book 14. International Ecology Institute, Oldendorf/Luhe, p 307 
Jönsson MT, Edman M, Jonsson BG (2008) Colonization and extinction patterns of wood-decaying fungi in a boreal old-growth Picea abies forest. J Ecol 96:1065-1075

Jonsson BG, Ekström M, Esseen PA, Grafström A, Ståhl G, Westerlund B (2016) Dead wood availability in managed Swedish forests-policy outcomes and implications for biodiversity. For Ecol Manage 376:174-182. https://doi.org/10.1016/j.foreco.2016.06.017

Karjalainen L, Kuuluvainen T (2002) Amount and diversity of coarse woody debris within a boreal forest landscape dominated by Pinus sylvestris in Vienansalo wilderness, eastern Fennoscandia. Silva Fenn 36:147-167

Keymer JE, Marquet PA, Velasco-Hernández JX, Levin SA (2000) Extinction thresholds and metapopulation persistence in dynamic landscapes. Am Nat 156:478-494

Korhonen KT, Tomppo E, Henttonen H, Ihalainen A, Tonteri T, Tuomainen T (2000) Pirkanmaan metsäkeskuksen alueen metsävarat 1965-1999. Metsätieteen Aikakauskirja 4B(2000):661-739

Kuuluvainen T, Aakala T (2011) Natural forest dynamics in boreal Fennoscandia: a review and classification. Silva Fenn 45:823-841

Kuuluvainen T, Mäki J, Karjalainen L, Lehtonen H (2002) Tree age distributions in old-growth forest sites in Vienansalo wilderness, eastern Fennoscandia. Silva Fenn 36:169-184

Kuuluvainen T, Aakala T, Várkonyi G (2017) Dead standing pine trees in a boreal forest landscape in the Kalevala National Park, northern Fennoscandia: amount, population characteristics and spatial pattern. For Ecosyst 4:12. https://doi.org/10.1186/s40663-017-0098-7

Lloyd S (ed) (1999) The last of the last: the old-growth forest of boreal Europe. Taiga Rescue Network, Jokkmokk

Öckinger E, Schweiger O, Crist TO, Debinski DM, Krauss J, Kuussaari M, Petersen JD, Pöyry J, Settele J, Summerville KS, Bommarco R (2010) Life-history traits predict species responses to habitat area and isolation: a cross-continental synthesis. Ecol Lett 13:969-979. https://doi.org/10.1111/j.1461-0248. 2010.01487.x

Östlund L, Zackrisson O, Axelsson AL (1997) The history and transformation of a Scandinavian boreal forest landscape since the 19th century. Can J For Res 27:1198-1206. https://doi.org/10.1139/x97-070

Owens IP, Bennett PM (2000) Ecological basis of extinction risk in birds: habitat loss versus human persecution and introduced predators. Proc Natl Acad Sci USA 97:12144-12148. https://doi.org/10. 1073/pnas.200223397

Pardini R, Bueno AdA, Gardner TA, Prado PI, Metzger JP (2010) Beyond the fragmentation threshold hypothesis: Regime shifts in biodiversity across fragmented landscapes. PLoS ONE 5(10):e13666. https://doi.org/10.1371/journal.pone.0013666

Pohlert T (2014) The pairwise multiple comparison of mean ranks package (PMCMR). R package. https:// CRAN.R-project.org/package=PMCMR. Accessed 22 Jan 2019

Purvis A, Jones K, Mace GM (2000) Extinction. BioEssays 22:1123-1133. https://doi.org/10.1002/15211878(200012)22:12<1123:AID-BIES10>3.0.CO;2-C

R Core Team (2018) R: A language and environment for statistical computing. R Foundation for Statistical Computing, Vienna, Austria. https://www.R-project.org/. Accessed 22 Jan 2019

Ranius T, Martikainen P, Kouki J (2011) Colonisation of ephemeral forest habitats by specialised species: beetles and bugs associated with recently dead aspen wood. Biodivers Conserv 20:2903-2915

Rassi P, Hyvärinen E, Juslén A, Mannerkoski I (eds) (2010) The 2010 red list of finnish species. Ministry of the Environment and Finnish Environment Institute, Helsinki

Rassi P, Karjalainen S, Clayhills T, Helve E, Hyvärinen E, Laurinharju E, Malmberg S, Mannerkoski I, Martikainen P, Mattila J, Muona J, Pentinsaari M, Rutanen I, Salokannel J, Siitonen J, Silfverberg H (2015) Kovakuoriaisten maakuntaluettelo 2015 (Provincial list of finnish coleoptera 2015). Sahlbergia 21. Supplement 1:1-164

Reigada C, Schreiber SJ, Altermatt F, Holyoak M (2015) Metapopulation dynamics on ephemeral patches. Am Nat 185:183-195

Rouvinen S, Kuuluvainen T, Karjalainen L (2002a) Coarse woody debris in old Pinus sylvestris dominated forests along a geographic and human impact gradient in boreal Fennoscandia. Can J For Res $32: 2184-2200$

Rouvinen S, Kuuluvainen T, Siitonen J (2002b) Tree mortality in a Pinus sylvestris dominated boreal forest landscape in Vienansalo wilderness, eastern Fennoscandia. Silva Fenn 36:127-145. https://doi.org/10. $14214 / \mathrm{sf} .554$

Schroeder LM, Ranius T, Ekbom B, Larsson S (2007) Spatial occurrence of a habitat-tracking saproxylic beetle inhabiting a managed forest landscape. Ecol Appl 17:900-909

Seibold S, Brandl R, Buse J, Hothorn T, Schmidl J, Thorn S, Müller J (2015) Association of extinction risk of saproxylic beetles with ecological degradation of forests in Europe. Conserv Biol 29:382-390 
Sverdrup-Thygeson A, Gustafsson L, Kouki J (2014) Spatial and temporal scales relevant for conservation of dead-wood associated species: current status and perspectives. Biodivers Conserv 23(3):513-535

Sverdrup-Thygeson A, Skarpaas O, Blumentrath S, Birkemoe T, Evju M (2017) Habitat connectivity affects specialist species richness more than generalists in veteran trees. For Ecol Manage 403:96-102

Siitonen J (2001) Forest management, coarse woody debris and saproxylic organisms: Fennoscandian boreal forests as an example. Ecol Bull 49:11-41

Silfverberg H (2010) Enumeratio renovata Coleopterorum Fennoscandiae, Daniae et Baltiae. Sahlbergia $16: 1-144$

Snäll T, Ribeiro PJ Jr, Rydin H (2003) Spatial occurrence and colonisations in patch-tracking metapopulation: local conditions versus dispersal. Oikos 103:566-578

Stokland J, Siitonen J, Jonsson BG (2012) Biodiversity in dead wood. Cambridge University Press, New York

Thomas CD (1994) Extinction, colonization and metapopulations: environmental tracking by rare species. Conserv Biol 8:373-378

Tomppo E, Tuomainen T, Henttonen H, Ihalainen A, Tonteri T (2003) Kainuun metsäkeskuksen alueen metsävarat 1969-2001. Metsätieteen Aikakauskirja 2B(2003):169-256

With KA, Crist TO (1995) Critical thresholds in species' responses to landscape structure. Ecology $76: 2446-2459$

Publisher's Note Springer Nature remains neutral with regard to jurisdictional claims in published maps and institutional affiliations.

\section{Affiliations}

\section{Mervi Laaksonen $^{1,2}$ (D) $\cdot$ Pekka Punttila $^{3} \cdot$ Juha Siitonen $^{4}$}

$\bowtie$ Mervi Laaksonen mervi.laaksonen@iki.fi

1 Present Address: Finnish Environment Institute, Friendship Park Research Centre, Lentiirantie 342, 88900 Kuhmo, Finland

2 University of Helsinki, Helsingin yliopisto, P.O. Box 65, 00014 Helsinki, Finland

3 Finnish Environment Institute, Latokartanonkaari 11, 00790 Helsinki, Finland

$4 \quad$ Natural Resources Institute Finland, P.O. Box 2, 00791 Helsinki, Finland 